\title{
Formulation of a Generalized Flow Curve for $0.2 \%$ Carbon Steel under High-speed Hot Forming Conditions by a Regression Method
}

\author{
Hyeon-Woo PARK ${ }^{1)^{*}}$, Kyunghyun $\mathrm{KIM}^{2)}$, Hyung-Won PARK $^{3)}$, Sheng Ding ${ }^{1)}$ and Jun Yanagimoto ${ }^{1)}$ \\ 1) Graduate School of Engineering, The University of Tokyo \\ 2) Makino Milling Machine Co., Ltd. \\ 3) Faculty of Production Systems Engineering and Sciences, Komatsu University
}

Abstract: A precise flow curve for a wide range of forming conditions is important for accurately predicting forming force. Moreover, since the flow curve reflects microstructural changes, its accurate description must be obtained under various temperatures and strain rates up to $300 \mathrm{~s}^{-1}$. For practical forming processes such as hot strip rolling and wire rod rolling, the deformation behavior at high strain rates $\left(50-200 \mathrm{~s}^{-1}\right)$ must also be studied. However, a uniform axial high strain rate is difficult to achieve. Hence, a new deceleration method is developed. Also, the compression test at high strain rates is accompanied by marked internal heat generation, therefore, temperature and deformation are highly inhomogeneous compared with those in tests at lower strain rates. In addition to this problem, heat conduction to the die and friction should be corrected using inverse analysis. By considering the internal temperature increase effect at high strain rates, the uniaxial flow curve obtained using inverse analysis is shown to be greater than the experimental apparent stress-axial strain curve. And then, a regression method is applied to obtain a generalized flow curve at high strain rates, which can cover wider ranges of strain rates and temperatures. Finally, they are compared with an extrapolated flow curve that is regressed using an intermediate strain rate in our previous research. By comparing those results, the extrapolated flow curve is greatly different from the flow curve obtained in the current research. To find the reason for the difference, a microstructure analysis using EBSD is implemented.

Keywords: high strain rate; flow curve; heat generation; regression; extrapolation.

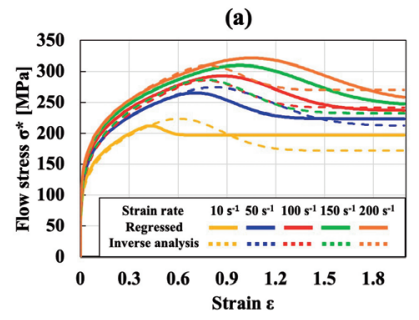

(c)

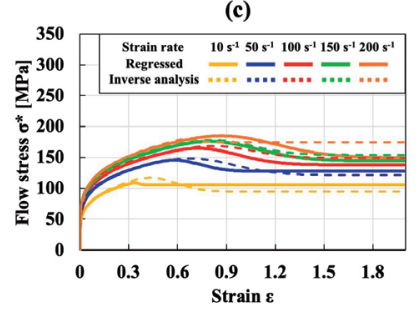

(b)

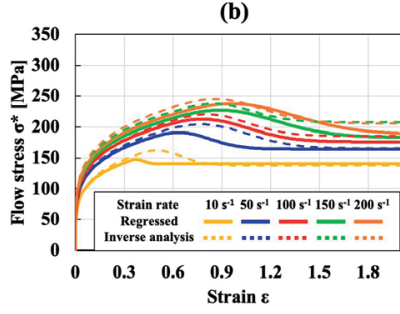

(d)

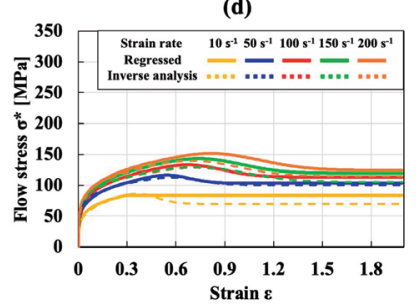

Received on Sep. 27, 2021; Accepted on Dec. 20, 2021; J-STAGE Advance published on Jan. 28, 2022; originally published in ISIJ Int., Vol.60 (2020), No.12, pp.2896-2904

* Corresponding author. E-mail: hyeonwoo.park@cem.t.u-tokyo.ac.jp, Address: The University of Tokyo, 7-3-1 Hongo Bunkyo-ku Tokyo 113-8656 


\title{
回帰法による高速熱間成形条件下での $0.2 \%$ 炭素鋼の流動応力統合式の定式化
}

\author{
朴 賢祐 ${ }^{1) *}$ ·金 勁賢 ${ }^{2)} \cdot$ 朴 亭原 ${ }^{3)} \cdot$ 丁 晟 ${ }^{1)} \cdot$ 柳本 潤 ${ }^{1)}$
}

Formulation of a Generalized Flow Curve for 0.2\% Carbon Steel under High-speed Hot Forming Conditions

by a Regression Method

Hyeon-Woo Park, Kyunghyun Kim, Hyung-Won Park, Sheng Ding and Jun Yanagimoto

\section{1. 緒言}

生産システムへの数值シミュレーションの応用は, 製造 プロセスの向上に当たって非常に重要である。このために は, 成形中の鉄鋼材料の塑性変形の, 固体力学に基づく予 測と正確な解析が必要である。また，塑性加工分野では， 適切な構成式を使用して金属材料の変形中の微細組織の変 化を数值的に予測し, 温度, ひずみ, ひずみ速度などの処 理条件を最適化しようとする研究がなされている ${ }^{1)}$ 。熱間 成形中の変形プロセスは，素材を所望の形状に成形するこ とを目的としているだけでなく, 変形と微細組織変化が密 接に関係しているため, 材料固有の機械的特性にも影響を 与える。また, 高温での微細組織の変化は, 流動応力曲線 に影響を与える。電子後方散乱回折 (EBSD), 走査型電子 顕微鏡 $(\mathrm{SEM})$ ，または透過型電子顕微鏡（TEM）を使用し た微細組織分析は, 成形後の低温状態の微細構造であって も，微細構造を明らかにするのに多くの時間と費用がかか る。ゆえに, 高温圧縮試験で得られた結果を使用して, 高 温での組織変化を予測するためには, 流動応力曲線を正確 に取得する必要がある。

得られた流動応力曲線は, 動的再結晶, 動的回復, 加工 硬化の影響を考慮した構成方程式や材料ゲノムを計算す るために使用できる2)。工具鋼 $\mathrm{SKD}^{2} 1^{3)}$ ，オーステナイト 系ステンレス鋼 $\mathrm{SUS} 316^{4)}$, 炭素鋼 $\mathrm{S} 15 \mathrm{C}^{5)}$ ，およびアルミニ ウム合金 $\mathrm{A} 5083 \mathrm{BE}-\mathrm{O}^{6)}$ の材料ゲノムはすでに取得されてい るが，これらは $50 \mathrm{~s}^{-1}$ 未満といった中ひずみ速度未満の速 度域で得られたものであるため, $50 \mathrm{~s}^{-1}$ を超える高ひずみ 速度域に拡張する必要がある。なぜなら実際の生産現場で は, 大型の厚板, 薄板材, 線材の熱間圧延, および一部の鍛 造および押出成形プロセスで, 高ひずみ速度での流動応力
曲線が特に必要となるからである。高速熱間成形試験機の 性能向上により, 現在では最大 $300 \mathrm{~s}^{-1}$ の軸方向ひずみ速 度で圧縮試験を行い, 荷重 - ストローク曲線を測定するこ とが可能となっている7)。しかしながら，一方で流動曲線 を取得する上で障壁となりうる重大な物理的問題がいくつ か存在するために，小規模な圧縮試験でも理想的な高速変 形を実現することは困難となっている。また, 高ひずみ速 度での流動応力曲線に関して検討すべき点もいくつか存在 する。

第一の点は, 試験機の応答と遅延時間の限界のため, 圧 縮工具の挙動を制御するのが難しいことである。これは, 変形時間が短く,ひずみ速度が高い圧縮試験では無視でき ない。試験片の変形時間は, $100 \mathrm{~s}^{-1}$ を超えるひずみ速度で $10 \mathrm{~ms}$ 未満であるため, 油圧プレスのラム運動のフィード バック制御はほとんど不可能である。ラム速度や軸方向ひ ずみ速度の変動は, 一軸流動応力を取得するときに逆解析 によって補正できるが, 軸方向ひずみ速度は可能な限り目 標值に近くあるべきである。

第二の点は試験機の弾性応答, 剛性の制限, およびラ ムと高温試験片の衝撃に起因して発生する振動の問題で ある ${ }^{8,9)}$ 。これゆえに得られる応力-ひずみ曲線には振動パ ターンが生じる。このような曲線の振動部分は, SavitzkyGolayフィルタリング法やハイパスフィルターを用いるこ となどによって数值的に除去する必要がある ${ }^{10)}$ 。

第三の点は, 高ひずみ速度の圧縮試験は, 低ひずみ速度 の試験よりも試験片の内部の温度上昇が大きいことであ る。また, 発熱量はひずみ速度に比例するために中心部か ら熱が放散するまでの時間が非常に短く, 中心部と表面の 温度差が大きくなる。したがって, 試験片内部に生じる不 均一な変形分布は, 高ひずみ速度の試験では特に重要にな

原著論文: ISIJ Int., Vol.60 (2020), No.12, pp.2896-2904

2021年9月27日受付２021年12月20日受理２022年1月28日J-STAGE早期公開 (Received on Sep. 27, 2021; Accepted on Dec. 20, 2021; J-STAGE Advance published on Jan. 28, 2022; originally published in ISIJ Int., Vol.60 (2020), No.12, pp.2896-2904)

1) 東京大学大学院工学系研究科 (Graduate School of Engineering, The University of Tokyo)

2) 牧野フライス製作所 (株) (Makino Milling Machine Co., Ltd.)

3）公立小松大学生産システム科学部 (Faculty of Production Systems Engineering and Sciences, Komatsu University)

* Corresponding author. E-mail: hyeonwoo.park@cem.t.u-tokyo.ac.jp, Address: The University of Tokyo, 7-3-1 Hongo Bunkyo-ku Tokyo 113-8656 
る可能性がある。このような問題は, 実験的に得られた見 かけの応力-ひずみ曲線に大きな誤差をもたらす要因とな りうる。この最も重要な第三の問題を解決して流動曲線を 取得するための方法として, 熱連成有限要素解析 (FEM) を用いて熱間圧縮実験をシミュレートすることで上記の影 響を補うことができる逆解析が導入されている ${ }^{11)}$ 。熱連成 FEM 解析を利用することによって, 実験的には測定するの が非常に難しい変形中の内部温度上昇量を求めることが可 能である。この一連の逆解析を利用して，0.2\%炭素鋼の高 温流動応力統合式の $50 \mathrm{~s}^{-1}$ のひずみ速度までの統合回帰式 が求められている ${ }^{12)}$ 。荷重-圧縮ストローク曲線から一軸 流動応力を取得するためのこの逆解析を利用すると，より 高速度の変形に起因する発熱量を補償することもできる。 しかしながら, $50 \mathrm{~s}^{-1}$ を上回る高ひずみ速度での流動応力 の統合回帰式は，どの種類の金属材料についてもいまだに 報告されていない。

本報ではより高いひずみ速度での高温流動応力を得る ことを目的として，上述の第一の問題を克服するために， 新しいストローク時間パターン生成方法を適用した。第二 の問題点に関しては以前の報告 ${ }^{10)}$ ですでに議論されてお り，その解決策は現在の研究にも適用されている。こうし た上で一連の高速圧縮試験と圧縮荷重 - ストローク曲線に 逆解析を適用することによって, 高温高速での流動応力曲 線が得られる。さらに逆解析により各ひずみ速度と温度条 件の一軸流動応力曲線を取得した後, 計算された流動曲線 の係数を回帰することにより, 広範囲の変形パラメータを カバーすることができる高ひずみ速度での流動応力統合式 を提案する。得られた流動曲線は, 以前の研究 ${ }^{12)}$ で取得さ れた低打よび中ひずみ速度での流動応力曲線と併用するこ とにより, 炭素鋼 S20Cの 1173〜1373 K の温度範囲と 10〜
$200 \mathrm{~s}^{-1}$ のひずみ速度範囲をカバーすることが可能である。 な打一般に，低打よび中ひずみ速度データから得られた流 動応力回帰曲線を使用して, 実験条件範囲外に適用する単 純な外挿法は，外挿範囲において未解明の現象がある場合 や，その現が発熱による温度上昇や応力低下に起因してい る可能性があるため, 望ましくない。

\section{2. 実験}

\section{$2 \cdot 1$ 圧縮試験機}

本研究での一軸圧縮実験は, Fig.1に示すサーボ油圧式高 速熱間成形シミュレーターThermecmaster-Z 15ton 試験機を 使用して行った。この試験機は, 最高温度 $1300^{\circ} \mathrm{C}$, 負荷あ りで最高ラム速度 $3500 \mathrm{~mm} \cdot \mathrm{s}^{-1}$, 負荷なしで $5000 \mathrm{~mm} \cdot \mathrm{s}^{-1}$ の条件で圧縮試験を実施できる。試験片の高さによっては, $300 \mathrm{~s}^{-1}$ を超える高いひずみ速度での試験も可能である。

この機械には, 水冷, ミスト冷却, 不活性ガス $\left(\mathrm{N}_{2}, \mathrm{He}\right)$ 冷却といった微細組織を制御するための 3 種類の冷却シス テムが装備されている。冷却応答時間は，ガスシステムで 0.1 秒, 水システムで 0.2 秒である。冷却速度は, ガスシス テムで最大 $30^{\circ} \mathrm{C} \cdot \mathrm{s}^{-1}$, 急冷システム (ミスト冷却なし) で 最大 $600^{\circ} \mathrm{C} \cdot \mathrm{s}^{-1}$ である。また圧縮前に $\mathrm{N}_{2}$ ガスで満たされる チャンバーを真空にするために, 真空システムが使用され る。 $\mathrm{N}_{2}$ を充填することによって試料の酸化を防ぐことがで き，この操作は流動応力曲線に酸化の影響がある材料には 重要である。また昇温は土50 kHzの高周波の電磁誘導加 熱により行われる。この誘導加熱システムにより, 温度を 正確に制御でき，加熱時間の短縮が可能である。一定の温 度を維持するために, PID フィードバックシステムが温度 制御に適用されており, 非常に短時間で一時的な温度変化
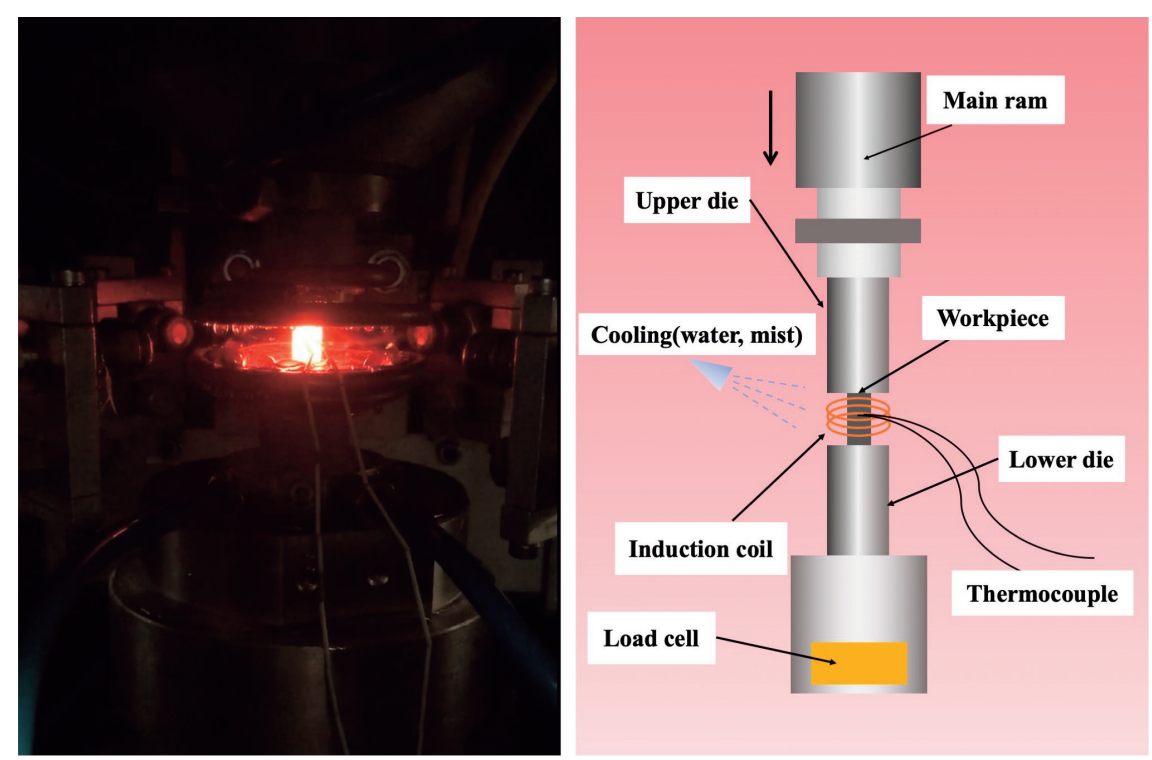

Fig. 1. A view of the experiment (left) and a schematic illustration of the high-speed compression test machine (right). (Online version in color.) 
を補正する。試料表面に $\mathrm{R}$ 型熱電対を取り付けて温度を測 定することで, 変形時の表面温度上昇も測定できる。試験 機には試験片の上下にそれぞれダイが備えられている。圧 縮は上部ダイで行い, 下部ダイは圧縮位置を変更するため に用いられることで, 高速多段圧縮試験が可能となってい る。両側のダイは窒化ケイ素 $\left(\mathrm{Si}_{3} \mathrm{~N}_{4}\right)$ 製であり, 弾性率 $E$ は 高いが密度 $\rho$ は低く, それらの比 $E / \rho$ である音速が大きい ことで, 高速変形による振動の影響を最小限に抑えること ができる。ラムの位置は, 容量がさ $60 \mathrm{~mm}$ のイナー電圧 差変圧器 (LVDT) によって測定される。この試験機の最大 荷重は $100 \mathrm{kN}$ であり, 荷重值は, 下部ダイの下に配置され たロードセルによって測定される。各データ值は, $1 \mathrm{MHz}$ のロガーサンプリング速度で収集される。

\section{$2 \cdot 2$ 実験条件}

本研究では $0.2 \%$ 低炭素鋼合金である S $20 \mathrm{C}$ 対象とし て実験を行なった。その化学組成を Table 1 に示す。実験前 に, 摩擦と熱伝達効果を最小限に抑えるために, 雲母シー トを試験片と試験機の間に挿入している。

試験片は円筒形で, 高さ $12 \mathrm{~mm}$, 直径 $8 \mathrm{~mm}$ である。圧縮 試験は試験片の高さがもとの 4 分の 1 となるまで行い, こ れを $10,50,100,150$, および $200 \mathrm{~s}^{-1}$ のひずみ速度に打い てそれぞれ実施した。フェライトの生成を抑制するため に, 圧縮は $900,1000,1100$, および $1200^{\circ} \mathrm{C}$ 高温で行われ, $0.2 \%$ 炭素鋼はオーステナイト単相である。圧縮前に, 試験 片を $10^{\circ} \mathrm{C} \cdot \mathrm{s}^{-1}$ の加熱速度で目標温度まで加熱した後 180 秒 間保持することにより完全なオーステナイト相を生成し, 試験片内の温度を均一に維持させ，内部ひずみを排除し， 等軸結晶粒のサイズを均質化した。この操作中の温度履歴 図をFig.2に示す。

Table 1. Chemical composition of the experiment material by weight percentage.

\begin{tabular}{ccccccccc}
\hline \multicolumn{1}{c}{ JIS-S20C $($ wt $\%)$} \\
\hline $\mathrm{C}$ & $\mathrm{Si}$ & $\mathrm{Mn}$ & $\mathrm{P}$ & $\mathrm{S}$ & $\mathrm{Cu}$ & $\mathrm{Cr}$ & $\mathrm{Ni}$ & $\mathrm{Fe}$ \\
\hline 0.2 & 0.2 & 0.42 & 0.02 & 0.023 & 0.1 & 0.1 & 0.1 & Bal. \\
\hline
\end{tabular}

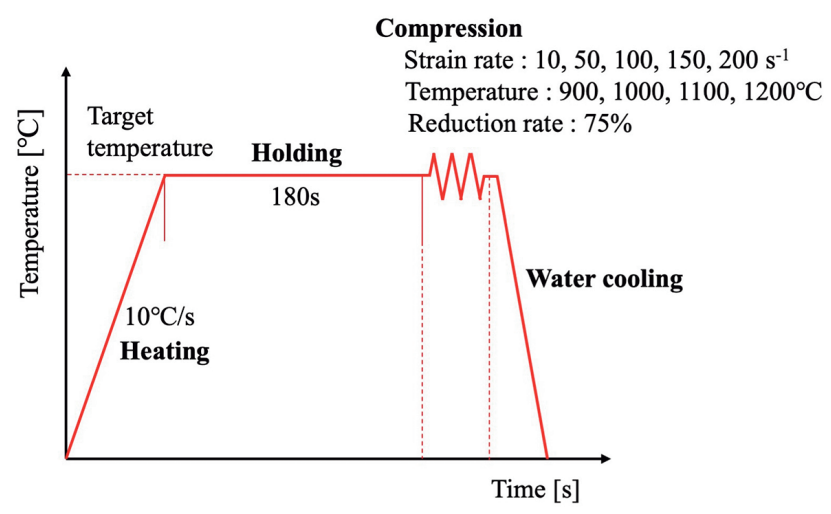

Fig. 2. Experimental conditions, temperature history, and quenching method. (Online version in color.)

\section{$2 \cdot 3$ ひずみ速度制御}

変形中において高ひずみ速度を均一に維持することは非 常に困難である。例えばひずみ速度とひずみがそれぞれ

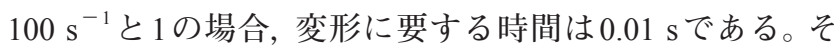
の場合，試験機の応答時間は約 0.004 秒であり，無視するこ とはできない。したがって，各パターンデータは，影響を 補正するために 0.004 秒分だけ延長されて記録される。ま た，圧縮開始から高いひずみ速度を実現することは困難で あるため, 圧縮前にラムを加速させる助走法を採用してい る ${ }^{8)}$ 。従来は, 変形時のストローク時間制御パターンの計 算に次の式を使用していた ${ }^{10)}$ 。

$$
h=h_{0} \exp (-\dot{\varepsilon} t)
$$

ここで, $h_{0}$ は試験片の初期高さ, $h$ は変形中のラムの瞬 間的な高さである。しかしながら, 助走法の適用において は別の問題が発生する。助走距離が短いためにラムの加速 は必ずしも十分では無く，また同時にラムを式 (1) に従っ て減速させるための新しい方法が必要である。圧縮が進み ことで試験片の高さが低くなると軸方向のひずみ速度が急 激に上昇し, 流動曲線の実験精度に影響を与える可能性が あるからである。

そこで本研究では, 以下に示すプロセスにてラムの減速 を行なった。その概略図はFig.3に示す。ここで，(1, 1) 表 示の先の 1 は繰り返し順番, 後の 1 は繰り返し順番中の手 順である。

(i ) 結果 $(1,1)$ を得るためのパターンを作成した。このパ ターンの作成では実際の結果 $(1,1)$ とパターン $(1,1)$ の時間差 $\Delta \mathrm{t}_{(1,1)}$ と, パターン $(1,2)$ とパターン $(1,1)$ の時間差 $\Delta \mathrm{t}_{(1,2)}$ が等しくなるものとした。

(ii) 結果 $(1,2)$ を取得した後, パターン $(1,3)$ とパターン $(1,1)$ の時間差 $\Delta \mathrm{t}_{(1,3)}$ と, パターン $(1,3)$ と結果 $(1,2)$ の間の時間差 $\Delta \mathrm{t}_{(1,4)}$ とが等しくなるようなパターン $(1$, 3）を作成した。

（iii）結果 $(1,3)$ を取得し, 以降は収束するまで手順全体を 繰り返して結果 $(n, 3)$ を取得した。

初期パターンとして, 式（1）を適用したストロークー時 間パターンを使用した。減速方法の概略図，およびひずみ 速度制御結果と減速前の結果を比較したものをFig. 3 に示 す ${ }^{10)}$ 。50 s${ }^{-1}$ のひずみ速度では, 減速方法なしで適切にラ 厶速度が制御されている一方で，ひずみ速度が $100 \mathrm{~s}^{-1}$ を 超えると, 減速法が有効であることが示されている。

\section{$2 \cdot 4$ 振動フィルタリング方法}

高ひずみ速度での試験では, 試験機の弾性応答による振 動が発生する。傾向全体を大きく歪めることなく精度を向 上させるための振動フィルタリング方法として, 本研究で はSavitzky-Golayフィルタリング法を適用した。著者らの 以前の研究より, 振動の影響を受ける応力 ${ }^{10)}$ は, 次のよう に記述される。 
$\sigma_{\text {exp }}=f\left(\sigma_{\mathrm{m}}, \sigma_{\text {noise }}\right)$

$\sigma_{\text {noise }} \cong \sigma_{\mathrm{xx}}=E \varepsilon_{\mathrm{xx}}=\frac{V_{0}}{w_{\mathrm{d}}} \cdot \sqrt{\rho E} \cdot e^{-\zeta w_{\mathrm{n}} t} \cdot \cos \left(w_{\mathrm{d}} t+\phi\right)$

ここで, $\sigma_{\mathrm{exp}}$ は実験で得られた応力, $\sigma_{\mathrm{m}}$ は材料の応力, $\sigma_{\mathrm{xx}}$ は圧縮方向の振動応力, $\varepsilon_{\mathrm{xx}}$ は圧縮方向の振動ひずみ, $\sigma_{\text {noise }}$ は圧縮試験機の弾性応答によって影響を受ける応力ノイズ である。 $E, \rho, V_{0}, \zeta, w_{\mathrm{n}}, w_{\mathrm{d}}$ は，それぞれ，弾性率，密度，圧 縮開始後の試験機の初速度, 臨界減衰係数, 機械システム の固有振動数，および減衰係数を含む固有振動数を示す。

\section{$2 \cdot 5$ 応力-ひずみ曲線}

軸方向の応力-ひずみ関係は, Suzuki ${ }^{13)}$ の方法でバル ジ変形を補償することで決定できるが，一軸の流動応力曲 線は, 実験的に得られた圧縮荷重 - ストロークデータの逆 解析によって同定できる ${ }^{11)}$ 。試験機の雲母の厚さ，たわみ の変化の補償，ストロークの補正も考慮に入れられてい
る。温度 $1000^{\circ} \mathrm{C}$ での振動補償された見かけの応力 - 軸方向 ひずみ曲線の結果を Fig.4に示す。

\section{3. 逆解析}

\section{$3 \cdot 1$ 流動応力曲線}

逆解析で使用される流動応力曲線の構成式は, Yanagida and Yanagimoto ${ }^{11)}$ によって提案されており, 変形中の軟化 現象が考慮されている。構成式は次のように表される。

$\left\{\begin{array}{ll}\bar{\sigma}=F_{1} \bar{\varepsilon}^{n} & \left(\bar{\varepsilon} \leq \varepsilon_{\mathrm{c}}\right) \\ \bar{\sigma}=F_{2} \exp \left[a\left(\bar{\varepsilon}-\varepsilon_{\max }\right)^{2}\right]+F_{3} & \left(\bar{\varepsilon} \leq \varepsilon_{\mathrm{c}}\right)\end{array}\right\}$

$\sigma_{\mathrm{f}}=\bar{\sigma} \cdot \dot{\varepsilon}^{m_{0}}$.

式 (4) で, $F_{1}$ (塑性係数),$n$ (加工硬化指数) , $\varepsilon_{\mathrm{c}}$ (臨界ひ ずみ)，执よび $F_{3}$ (定常応力）は，逆解析によって取得でき る独立パラメータである。これらはすべて材料定数であ (a)

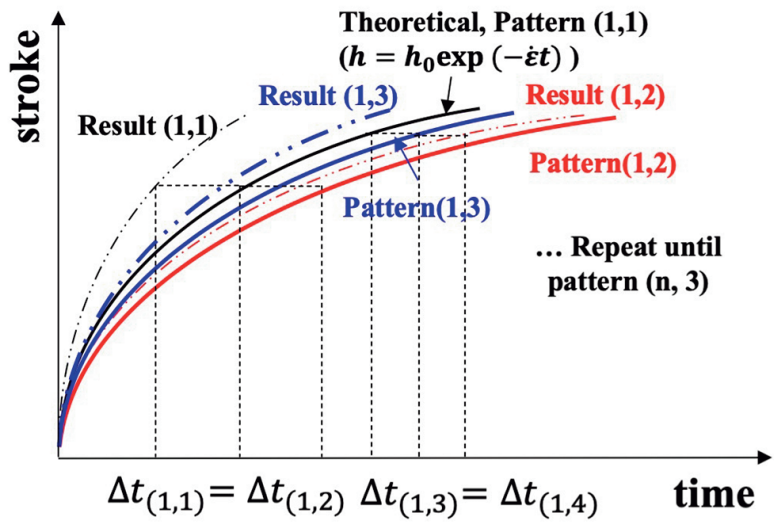

(b)

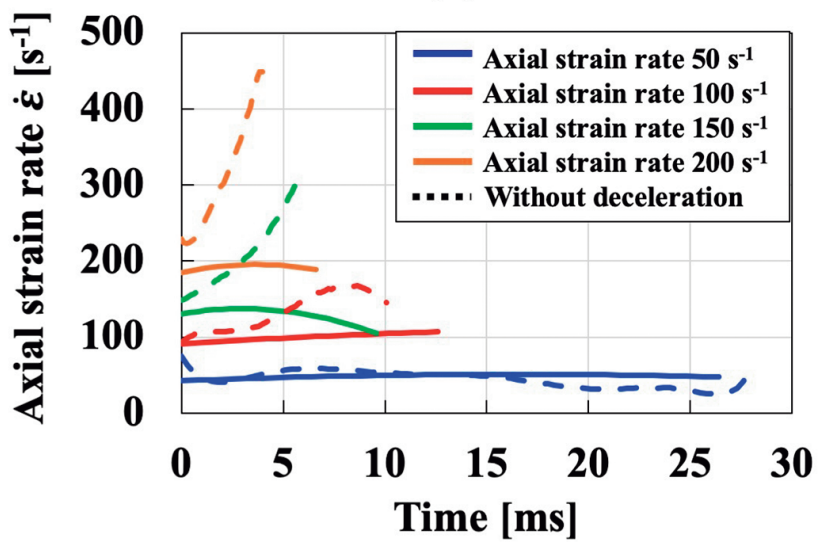

Fig. 3. (a) A schematic illustration of the deceleration control method for the high-strain-rate compression test, and (b) the axial strain rate result comparison at the temperature of $1000^{\circ} \mathrm{C}$ between the previous method ${ }^{10)}$, and the deceleration method. (Online version in color.)

(a)

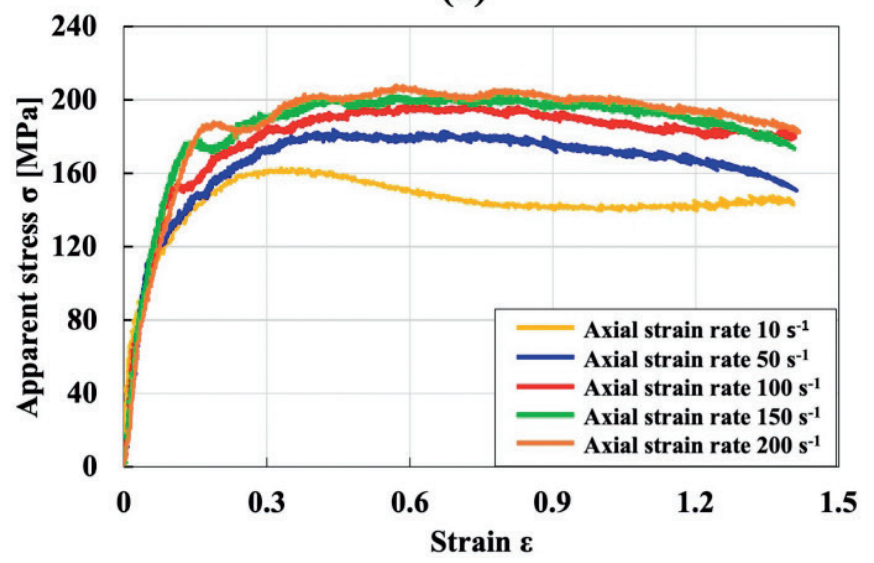

(b)

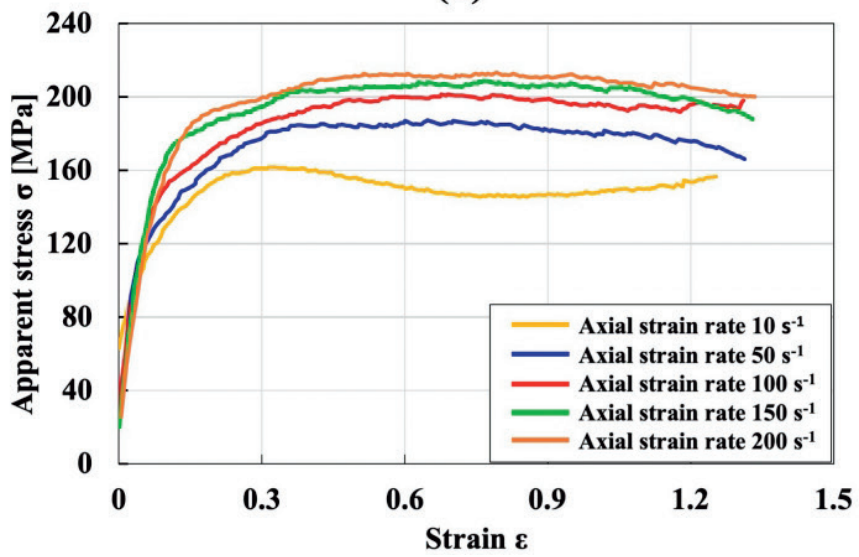

Fig. 4. Apparent stress-axial strain curve at the temperature of $1000^{\circ} \mathrm{C}$ (a) before filtering, and (b) after filtering out vibration patterns. (Online version in color.) 
り，明確な個々の物理的意味を持っている。式 (5) のひず み速度の影響を補償した流動応力を取得するにあたって は，ひずみ速度とひずみ速度依存指数 $m_{0}$ を考慮した。 $m_{0}=$ $\left(1.6 \times 10^{-4}\right) T-0.1031$ を $m_{0}$ の初期值に用いた ${ }^{2)} 。 T$ は変 形時の温度である。

\section{$3 \cdot 2$ 内部温度分布}

内部温度分布は, 逆解析中に組み込まれている熱連成 FEAを用いて取得することができ, 次の式を使用して計算 される。

$$
\rho c\left(\frac{\partial T}{\partial t}-v_{r} \frac{\partial T}{\partial r}\right)=\frac{\kappa}{r}\left(r \frac{\partial^{2} T}{\partial r^{2}}+r \frac{\partial^{2} T}{\partial z^{2}}\right)+\dot{Q}
$$

$$
\dot{Q}=\sigma_{\mathrm{f}} \dot{\varepsilon}+\dot{q}_{\mathrm{e}}
$$

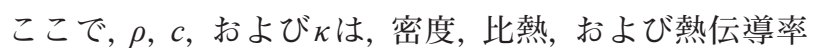
を表す。また, $\dot{Q}$ は内部総発熱量, $\sigma_{\mathrm{f}} \dot{\varepsilon}$ は塑性加工による発 熱量, $\dot{q}_{\mathrm{e}}$ は誘導加熱の電磁的要因による発熱量である。式 （7）からわかるように，ひずみ速度が高いほど系は断熱 的になりより内部発熱の影響が大きくなる。この傾向は Vazquez-FernandezらおよびSeidt らによってIRカメラを使 用して実験的に実証されている ${ }^{14,15)}$ 。変形前の初期温度分 布状態と各ひずみ速度に打ける $75 \%$ 圧下率での温度分布 を可視化した結果を Fig.5に示す。Fig.5から, 温度が試験 片の中央部分で高く, 表面部分が低いこと, またひずみ速 度が大きくなるとその差が大きくなることが分かる。中 央部分の最高温度は, ひずみ速度が $200 \mathrm{~s}^{-1}$ の場合では約 $1061^{\circ} \mathrm{C}$ に達する一方で，ひずみ速度が $10 \mathrm{~s}^{-1}$ の場合では $1022.4^{\circ} \mathrm{C}$ にし達しない。言い換えれば, 試験片は高ひず み速度でより不均一に変形していると結論付けることがで
きる。その影響を補償した逆解析から求めた流動応力の結 果を Fig.6に示す。式 (4) の流動応力 $\bar{\sigma}$ は， $T_{0}$ を基準温度と して以下のように求められる。

$$
\left.\bar{\sigma}\right|_{T}=\left.\bar{\sigma}\right|_{T_{0}} \frac{\exp \left(A_{0} / T\right)}{\exp \left(A_{0} / T_{0}\right)}
$$

式 (5) の $\bar{\sigma}$ の代わりに式 (8) の $\bar{\sigma}_{T}$ を使用することによつ て, 逆解析で得られる流動応力曲線は次のようになる。

$$
\left.\bar{\sigma}_{\mathrm{f}}\right|_{T}=\left.\bar{\sigma}\right|_{T} \cdot \dot{\varepsilon}^{m_{0}}
$$

ここで初期温度依存指数 $A_{0}$ は4 4260 である ${ }^{12)}$ 。ここで, $\bar{\sigma}_{T}$ は温度補正された流動応力を示し, $\bar{\sigma} \mid T_{0}$ は基準温度での応 力を示す。したがって, 温度が上昇すると, 特定の箇所で の応力が低くなる。このような影響により, Fig.4の温度 $1000^{\circ} \mathrm{C}$ での実験から得られた見かけの応力-軸方向ひずみ 曲線は, 逆解析によって得られた一軸流動応力曲線とは 完全に異なることが分かる。Fig.6 (b) での逆解析による 流動応力の同定の際の実験荷重と計算荷重の間の誤差は, Modified Lavenberg-Marquardt法によって $3 \%$ 未満に抑えら れている。

Fig.7は, 逆解析で得られた流動応力が, 内部発熱の影響 のために実験で測定されたものよりも大きくなっているこ とを示している。計算中, 温度の上昇は, 解析荷重と実験 荷重の両方に反映される。逆解析を使用して流動応力を同 定計算した結果として, 流動応力曲線の各独立パラメータ が取得される。Fig.7（b）に示すように構成式に基準温度を 適用すると, 流動応力が増加する。Fig.6 (b) と Fig.4の間で 見られる差は，理論的に説明ができることを示している。 (a)

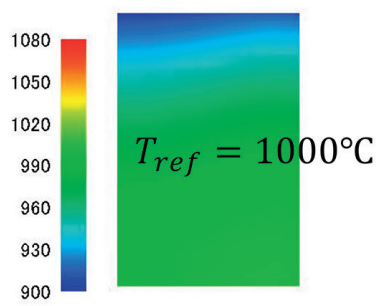

(d)

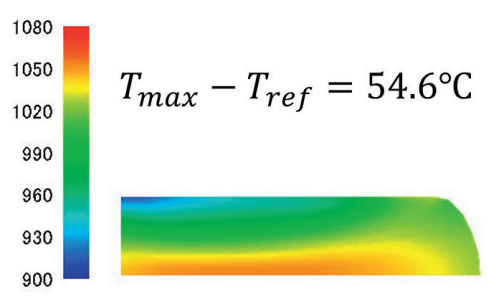

(b)

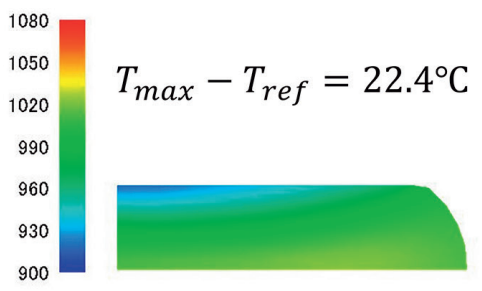

(e)

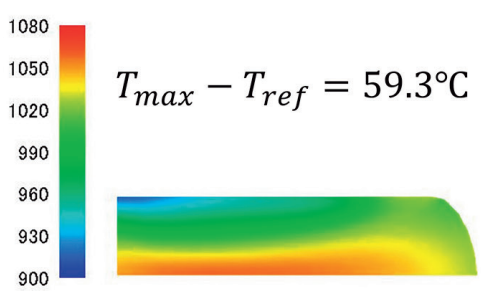

(c)

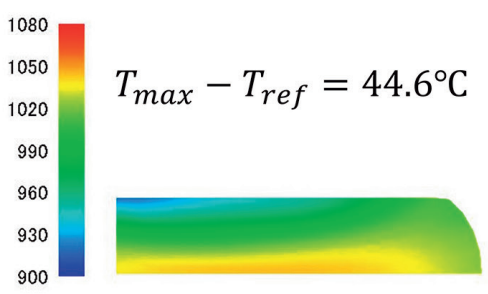

(f)

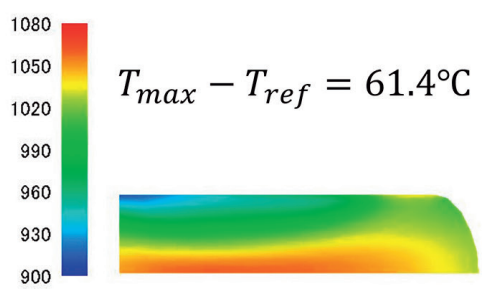

Fig. 5. Internal temperature distribution at $1000^{\circ} \mathrm{C}$ (a) before compression, and at the strain rates of (b) 10 , (c) 50 , (d) 100 , (e) 150 , and (f) $200 \mathrm{~s}^{-1}$. (Online version in color.) 


\section{4. 流動応力の統合式}

\section{$4 \cdot 1$ 流動応力の回帰}

Fig.6の逆解析による流動応力の同定結果に示されてい るように, 各温度における高ひずみ速度圧縮試験での流動 応力曲線の傾向は規則的ではなく, 大きな䛊差が存在して いる。したがって，それらの正しい関係を決定し，統合化 された流動応力 $\sigma^{*}$ を取得するには，回帰プロセスが必要で ある。このためには流動応力式の中のすべての独立したパ ラメータ $F_{1}, \varepsilon_{\mathrm{c}}, n, F_{3}$ 打よび初期ひずみ速度依存指数 $m_{0}$ と

(a)

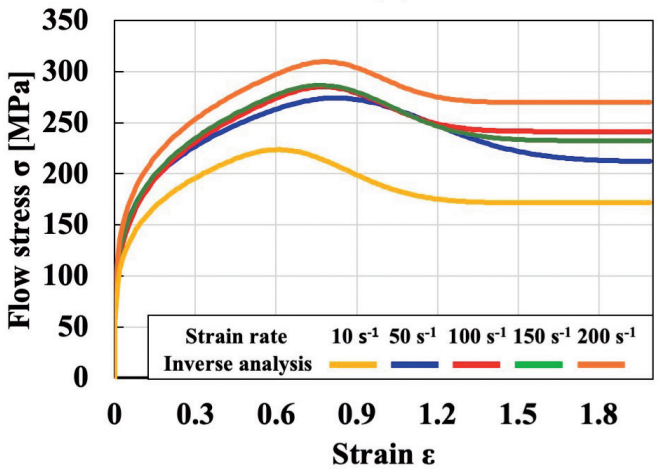

(c)

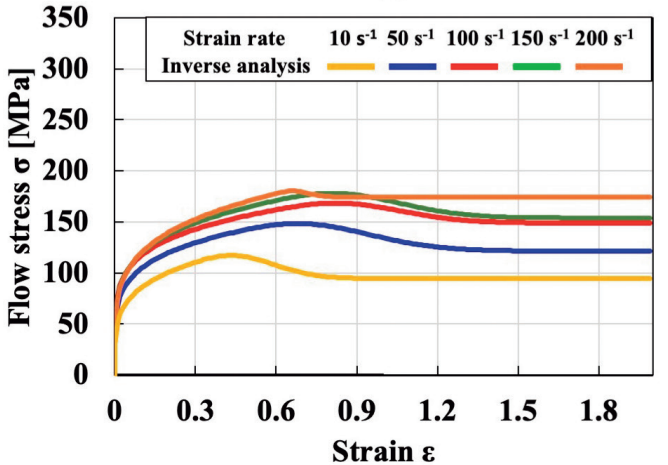

初期温度依存指数 $A_{0}$ をそれぞれ $F_{1}{ }^{*}, \varepsilon_{\mathrm{c}}{ }^{*}, \bar{n}, F_{3}{ }^{*}, m, A$ に変 換する必要がある ${ }^{12)}$ 。動的再結晶の開始点となる臨界ひず み $\varepsilon_{\mathrm{c}}$ は条件によって異なるため, 本研究では次式を用いて フィッティングを行った。

$$
\varepsilon_{\mathrm{c}}=a \cdot\left(\dot{\varepsilon} \exp \left(\frac{c}{T}\right)\right)^{b}
$$

フィッティングを最適化することにより, 式 (10) 中の 定数 $a, b, c$ をそれぞれ0.096，0.197，5441.153に決定した。 フィッティング結果とデータ点を Fig.8に示す。逆解析に

(b)

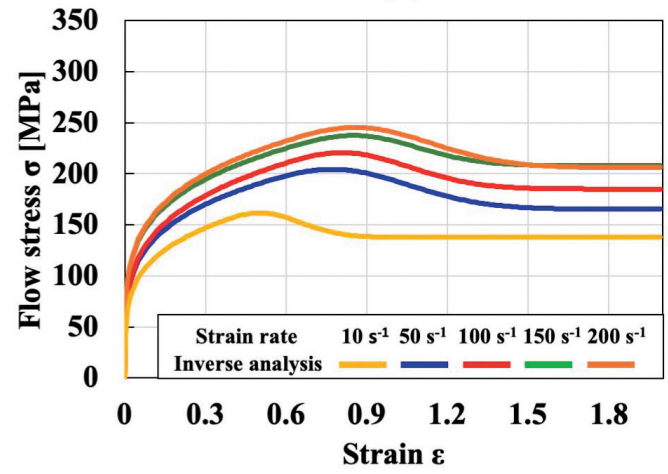

(d)

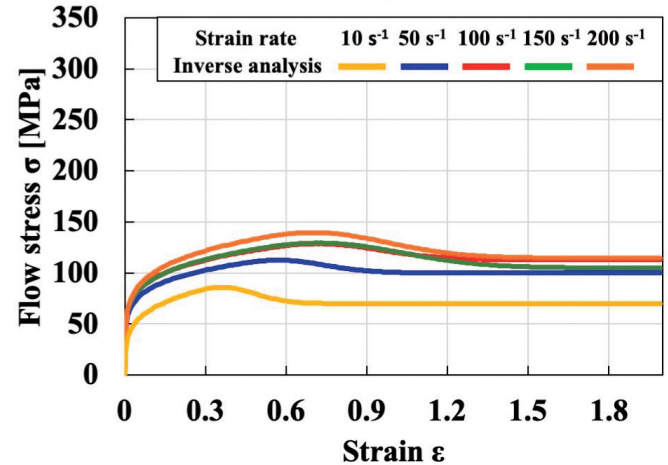

Fig. 6. Flow curves obtained by inverse analysis at temperatures of (a) 900 , (b) 1000 , (c) 1100 , and (d) $1200^{\circ} \mathrm{C}$. (Online version in color.)

(a)

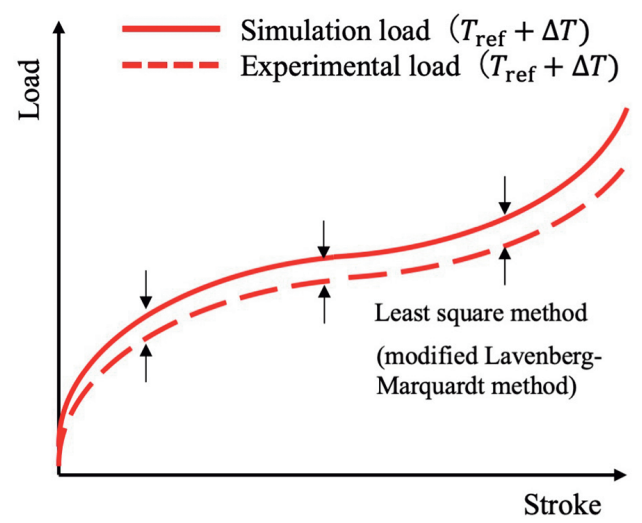

(b)

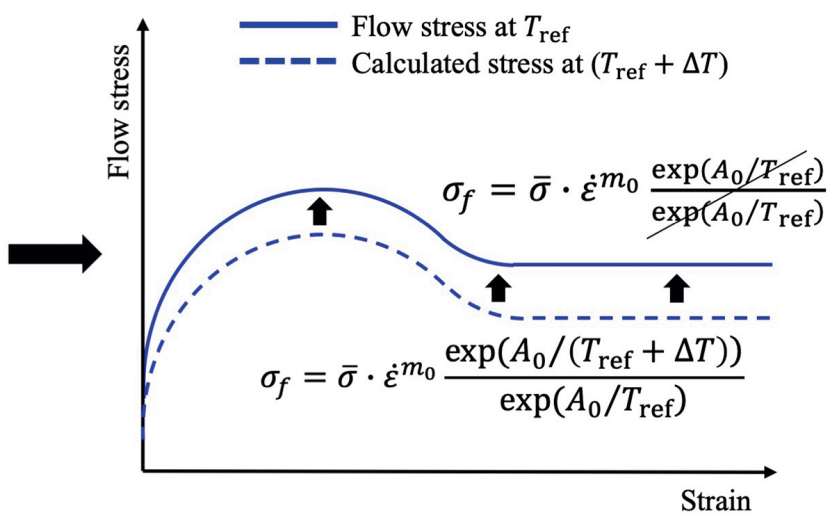

Fig. 7. Schematic illustrations of (a) the inverse analysis calculation using temperature-increase-reflected load data and (b) the flow stress increase after applying the reference temperature. (Online version in color.) 


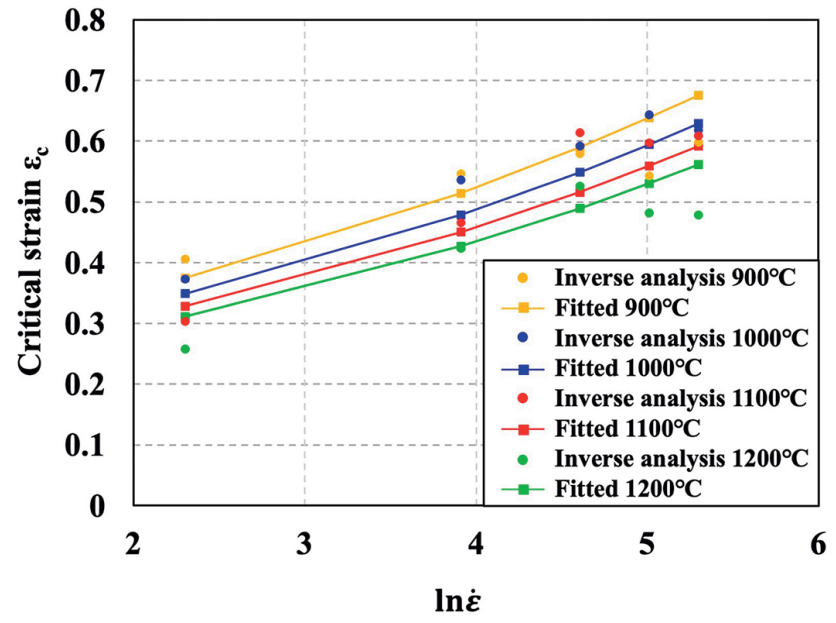

Fig. 8. Regression of critical strain $\varepsilon_{c}$ obtained by inverse analysis. (Online version in color.)

Table 2. Regressed independent parameters $\left(F_{1}^{*}, \varepsilon_{\mathrm{c}}{ }^{*}, \bar{n}\right.$, and $\left.F_{3}{ }^{*}\right)$ and sensitivities ( $m$ and A).

\begin{tabular}{cccc}
\hline \multirow{2}{*}{ Independent parameters } & $\boldsymbol{F}_{1}{ }^{*}$ & $\overline{\boldsymbol{n}}$ & $\boldsymbol{F}_{3}{ }^{*}$ \\
\cline { 2 - 3 } & 123.6 & 0.212 & 94.64 \\
\hline Strain rate sensitivity $\boldsymbol{m}$ & \multicolumn{1}{c}{$=\left(-2.8 \times 10^{-7}\right) \cdot T^{2}+0.00092 \cdot T-0.614$} \\
\hline Reference temperature $\boldsymbol{T}^{*}$ & \multicolumn{2}{c}{$1323 \mathrm{~K}$} \\
\hline Temperature sensitivity A & \multicolumn{2}{c}{5628.5} \\
\hline Critical strain $\boldsymbol{\varepsilon}_{c}{ }^{*}$ & $\boldsymbol{\varepsilon}_{\mathrm{c}}{ }^{*}=0.096 \cdot\left(\dot{\varepsilon} \cdot \exp \frac{5441.15}{T}\right)^{0.197}$ \\
\hline
\end{tabular}

(a)

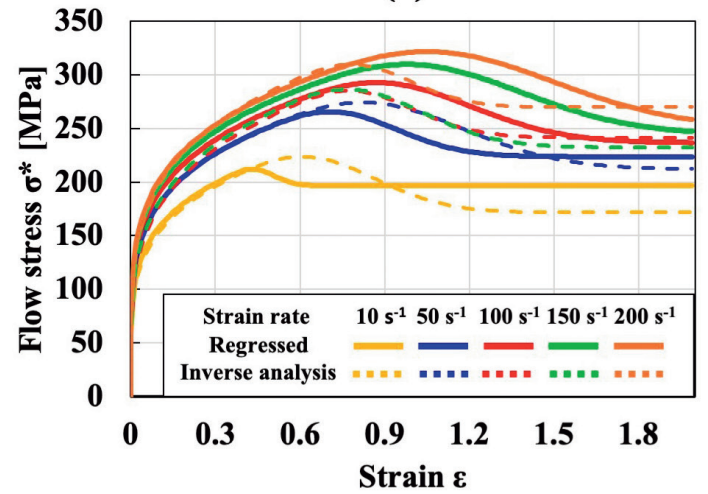

(c)

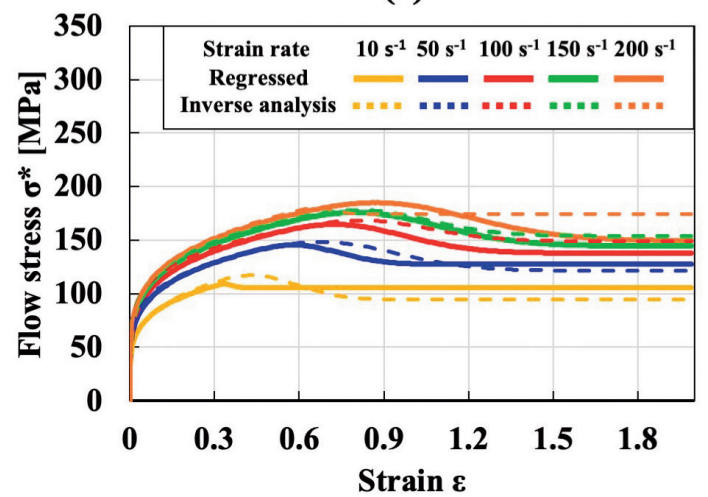

よる臨界ひずみは，一般に $100 \mathrm{~s}^{-1}$ 未満のひずみ速度では ひずみ速度に比例して増加するが, $100 \mathrm{~s}^{-1}$ を超えるひずみ 速度にはその限りではない。臨界ひずみとひずみ速度の関 係については未だ議論がなされている。Senumaらは臨界 ひずみとひずみ速度は無関係であると主張した ${ }^{1)}$ が, 最近 では臨界ひずみとひずみ速度の比例関係を示す研究結果が 増えている ${ }^{16)}$

臨界ひずみでの関数の連続性を考慮することにより, 従属パラメータ $F_{2}, \varepsilon_{\max }, a$ は, 回帰された独立パラメータ $F_{1}{ }^{*}, \varepsilon_{\mathrm{c}}{ }^{*}, \bar{n}, F_{3}^{*}$ を使用して，それぞれ $F_{2}^{*} ， \varepsilon_{\text {max }}{ }^{*}, a^{*}$ に変換さ れる。決定されたすべてのパラメータを Table 2 に示す。こ れらを使用すると, 流動応力統合式曲線の完全な定式化は 次のように表される。

$$
\begin{aligned}
\sigma^{*} & =\dot{\varepsilon}^{m} \exp \left[A\left(\frac{1}{T}-\frac{1}{T^{*}}\right)\right] \\
& \left\{\begin{array}{ll}
\bar{\sigma}=F_{1}^{*} \bar{\varepsilon}^{\bar{n}} & \left(\bar{\varepsilon} \leq \varepsilon_{\mathrm{c}}^{*}\right) \\
\bar{\sigma}=F_{2}^{*} \exp \left[a^{*}\left(\bar{\varepsilon}-\varepsilon_{\max }\right)^{2}\right]+F_{3}^{*} & \left(\bar{\varepsilon} \leq \varepsilon_{\mathrm{c}}^{*}\right)
\end{array}\right\}
\end{aligned}
$$

式（11）を用い，10２00 $\mathrm{s}^{-1}$ のひずみ速度圧縮試験での 0.2\%炭素鋼の流動応力統合式曲線を描いた結果を Fig. 9 に 示す。図中にはFig.6で示した逆解析によって得られた流 動曲線も再揭している。この結果より, 流動応力が最大応 力の後に急激に低下していることが明らかとなっている。

(b)

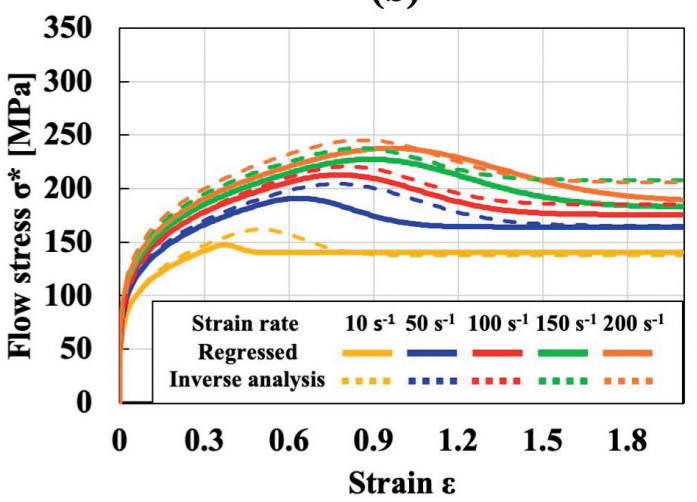

(d)

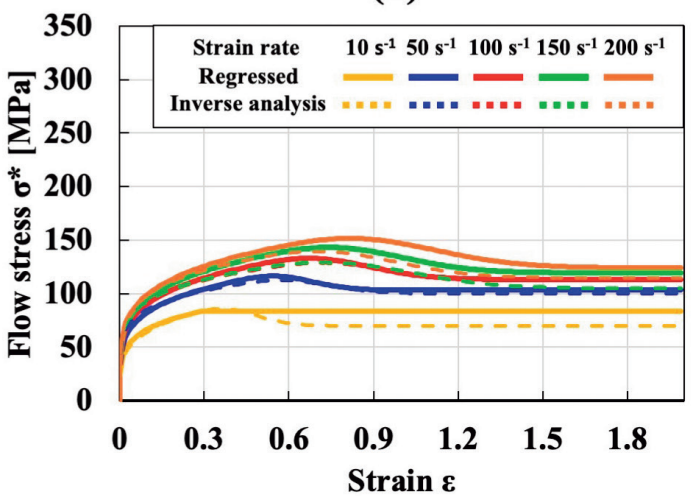

Fig. 9. Regressed flow curves at temperatures of (a) 900, (b) 1000 , (c) 1100 , and (d) $1200^{\circ} \mathrm{C}$. (Online version in color.) 
Jonas らは外挿法により高ひずみ速度試験での流動応力曲 線を取得しここれがDRX（Dynamic Recrystallization）型の 流動応力曲線であることを示した ${ }^{17)}$ 。彼らは，ひずみ速度 が高いほど，DRX体積分率が大きくなると想定した。また 高ひずみ速度が変形中に双晶構造をもたらすことを示した 研究結果も報じられている。Mandalらは高ひずみ速度での 変形中に発生する双晶構造は, DRXの核形成サイトになり うると主張した ${ }^{18)}$ 。しかしながら Yanagida and Yanagimoto の DRX連続生成モデルは高ひずみ速度で流動応力が軟 化現象を反映するDRXタイプになる場合でも，実際の動 的再結晶率と体積分率が非常に低くなることも示してい る ${ }^{19)}$ 。

\section{$4 \cdot 2$ 中ひずみ速度での回帰流動応力曲線との比較}

流動応力曲線の完全な形式は, $50 \sim 200 \mathrm{~s}^{-1}$ のひずみ速度 域においては次のように記述される。

$$
\sigma^{*}=\bar{\sigma} \cdot \dot{\varepsilon}^{\left\{\left(-2.8 \times 10^{-7}\right) \cdot T^{2}+0.00092 T-0.614\right\}} \exp \left[5628.5\left(\frac{1}{T}-\frac{1}{1323}\right)\right]
$$

$$
\begin{aligned}
& \left\{\begin{array}{ll}
\bar{\sigma}=123.6 \cdot \bar{\varepsilon}^{0.212} & \left(\bar{\varepsilon} \leq \varepsilon_{\mathrm{c}}^{*}\right) \\
\bar{\sigma}=F_{2}^{*} \exp \left[a^{*}\left(\bar{\varepsilon}-\varepsilon_{\max }\right)^{2}\right]+94.64 & \left(\bar{\varepsilon} \geq \varepsilon_{\mathrm{c}}^{*}\right)
\end{array}\right\} \\
& \varepsilon_{\mathrm{c}}^{*}=0.096 \cdot\left(\dot{\varepsilon} \exp \left(\frac{5441.15}{T}\right)\right)^{0.197} \ldots \ldots \ldots \ldots \ldots \ldots \ldots \ldots \ldots \ldots \ldots \ldots \ldots \ldots
\end{aligned}
$$

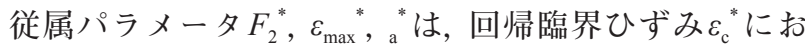
ける関数連続の仮定を適用することによって取得すること ができる。それらの式は次のように表される。

$$
\varepsilon_{\max }^{*}=\varepsilon_{\mathrm{c}}^{*}+\frac{F_{1}^{*} \varepsilon_{\mathrm{c}}^{* \bar{n}}-F_{3}^{*}}{\bar{n} F_{1}^{*} \varepsilon_{\mathrm{c}}{ }^{* \bar{n}-1}-(\bar{n}-1)\left(F_{1}^{*} \varepsilon_{\mathrm{c}}{ }^{* \bar{n}}-F_{3}^{*}\right) \varepsilon_{\mathrm{c}}{ }^{*-1}}
$$

(a)

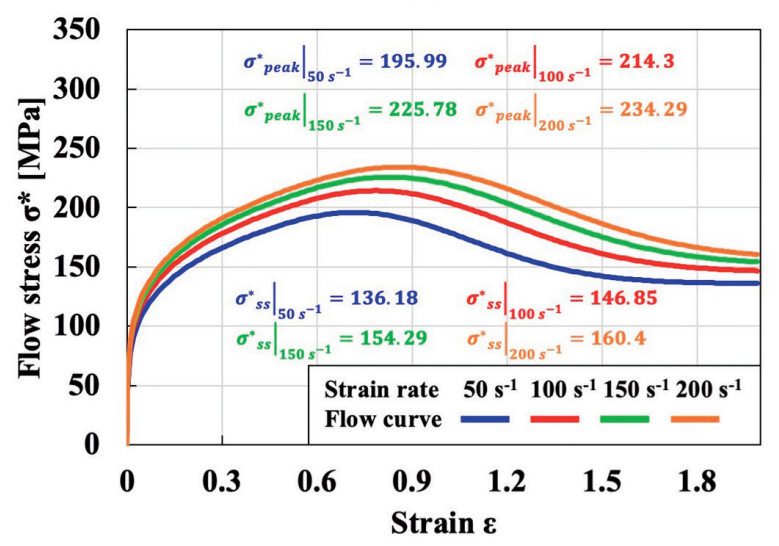

$$
\begin{aligned}
& a^{*}=\frac{\bar{n} F_{1}^{*} \varepsilon_{\mathrm{c}}{ }^{* \bar{n}-1}}{2\left(\varepsilon_{\mathrm{c}}{ }^{*}-\varepsilon_{\max }{ }^{*}\right)\left(F_{1}{ }^{*} \varepsilon_{\mathrm{c}}{ }^{* \bar{n}}-F_{3}{ }^{*}\right)} \\
& F_{2}^{*}=\frac{F_{1}^{*} \varepsilon_{\mathrm{c}}^{* \bar{n}}-F_{3}^{*}}{\exp \left[a^{*}\left(\bar{\varepsilon}-\varepsilon_{\max }{ }^{*}\right)^{2}\right]}
\end{aligned}
$$

$1,10,50 \mathrm{~s}^{-1}$ の中ひずみ速度で得られた結果を使用し て回帰された流動応力曲線は, Yanagida and Yanagimotoに よって取得されている ${ }^{12)}$ 。これを使用して，1000 ${ }^{\circ} \mathrm{C}$ 温度 と $50,100,150,200 \mathrm{~s}^{-1}$ のひずみ速度での流動応力曲線を 計算することが可能である。この式 ${ }^{12)}$ から外挿された流動 応力曲線は, 本研究の高ひずみ速度で新たに求めた流動応 力統合式曲線とともにFig.10に示されている。

2つの結果の全体的なピーク応力レベルはそれほど違い がないが, 外挿された曲線の定常状態の応力は, 本研究で 得られた流動曲線よりも低くなっている。また，本研究に おける臨界ひずみは，外挿された曲線から得られたものよ りも0.05ほど高くなっている。上記の結果から得られた温 度依存指数 $A$ は 5628 であるのに対し, 以前の研究で得られ たものは4260であった。3・2節で述べたように，この外挿 された流動応力曲線と本研究で得られた流動応力曲線との 応力差は, 高ひずみ速度での変形中の大幅な温度上昇を反 映する逆解析を用いることによって明らかにされたもので ある。高いひずみ速度の変形に起因する治金学的現象が生 じたことによって, 以上のような応力の温度依存性指数の 変化が発生した可能性があると考える。

\section{EBSD分析}

高ひずみ速度範囲での流動応力曲線に対する変形速度の 影響を調べるため，電界放出型走査電子顕微鏡 (FE-SEM, JEOL 7100 F) を備えた EBSD (Electron Backscatter Diffraction)

(b)

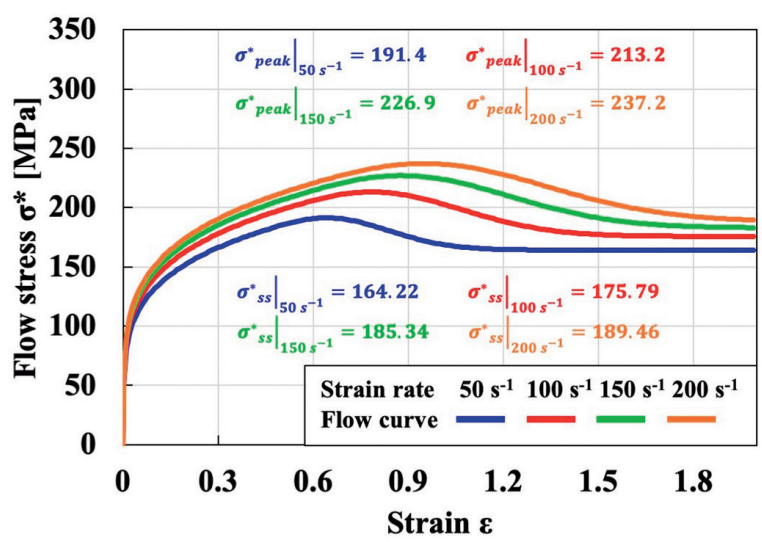

Fig. 10. (a) Extrapolated flow curve regressed from an intermediate strain rate and (b) flow curve at high strain rates obtained in the current investigation. (Online version in color.) 
(a)

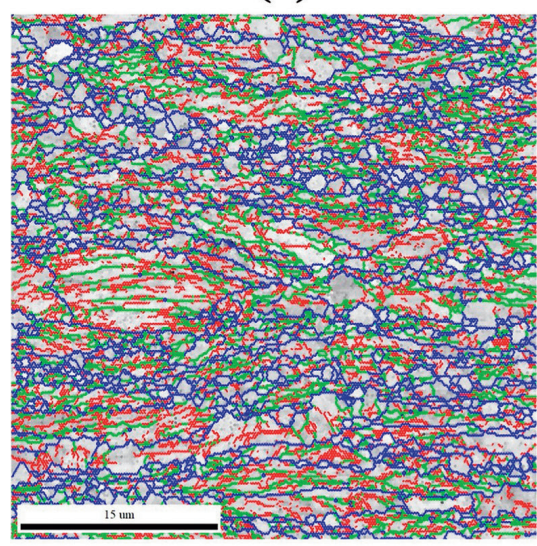

(b)

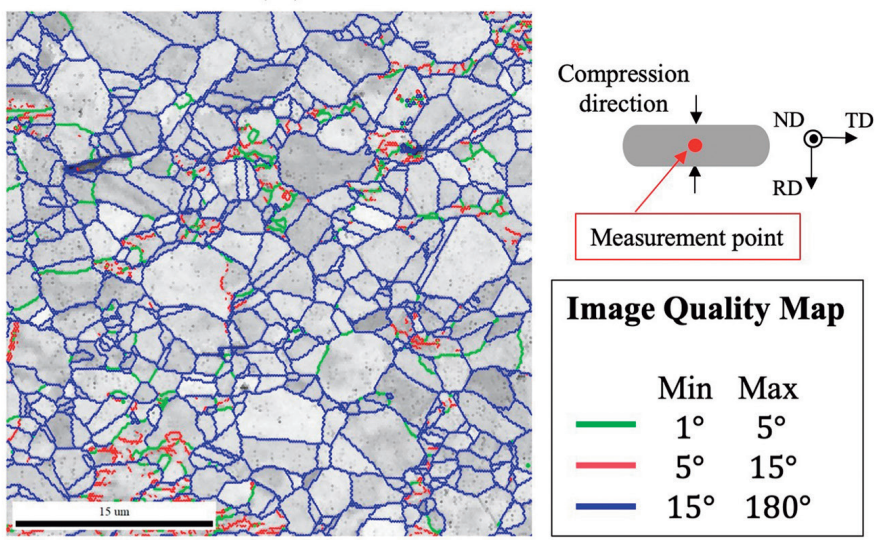

Fig. 11. Image quality maps obtained by EBSD using SUS316 austenitic stainless steel at initial temperature of $1000^{\circ} \mathrm{C}, 75 \%$ reduction rate of height, and strain rates of (a) 50 , and (b) $200 \mathrm{~s}^{-1}$. (Online version in color.)

分析を行い, 微細組織の観察を実施した。なお $0.2 \%$ 炭素 合金鋼は高温でオーステナイトから冷却後にフェライト， パーライト, マルテンサイト組織に変化するため, 微細組 織のEBSD分析には相変化の生じないSUS316オーステナ イト系ステンレス鋼を用いた。压縮試験を行って変形させ た試験片をカッターで圧縮方向に半分に切断してホット マウントし, OP-Uノンドライ コロイダルシリカ懸濁液 (Struers 社製) を使用して研磨した。それらの比較結果を Fig.11に示す。初期温度 $1000^{\circ} \mathrm{C}$ で $2 つ$ 異なるひずみ速度 $50,200 \mathrm{~s}^{-1}$ の条件で変形させた試験片に対して微細組織を スキャンした。

$200 \mathrm{~s}^{-1}$ の高ひずみ速度で双晶組織が多く見られるのに 対し, $50 \mathrm{~s}^{-1}$ では双晶組織が少ないことが示されている。 面心立方格子構造 (Face-Centered Cubic, FCC) を有する金 属や積層欠陥エネルギー（Stacking Fault Energy, SFE）の低 い材料の変形中に扎いて, 双晶生成は加工硬化速度の増加 につながることが知られている ${ }^{20)}$ 。高ひずみ速度での塑性 加工によって材料内部の温度が上昇すること，あるいはそ もそも変形速度自体が高くなることによって結晶粒界の移 動量の増加につながり, 最終的には双晶生成を加速する可 能性がある ${ }^{21)}$ 。さらに, $200 \mathrm{~s}^{-1}$ ひずみ速度でのDRXの結 晶粒サイズは一般に小さなものとなっているが, $50 \mathrm{~s}^{-1}$ の ひずみ速度で変形した結晶粒サイズははるかに小さくなっ ている。S20CとSUS316鋼の化学的性質が完全に異なるも のの，上記の結果から，逆解析を使用して流動応力曲線を 取得するために高速変形試験を行う必要があることが分か る。これらの材料間の違いとして, SUS316の実験では変形 した試験片はひずみ速度が低いと結晶粒径がはるかに小さ くなるが，炭素鋼ではひずみ速度が大きいほど動的再結晶 の結晶粒径が小さくなるという点がある ${ }^{1)}$ 。Fig.10から, 流 動応力の変化には双晶形成の寄与が含まれているために単 純な外挿ではひずみ速度間の流動応力の違いを反映するこ とは不可能であると考える。この結果から, 中ひずみ速度
データを使用して回帰した流動応力統合式曲線からの外挿 流動応力は, 高速圧縮試験によって直接得られた結果とは 異なると結論付けることができる。

\section{6. 結言}

高温および高ひずみ速度での $0.2 \%$ 炭素鋼の流動応力曲 線について研究を実施した。

（1）Thermecmaster-Z 15 トン試験機の特殊な制御方法を用 いることでラム速度の減速を行い，均一な軸方向ひず み速度での高速圧縮試験を実現した。

（2）圧縮試験機の $1000 \mathrm{~Hz}$ の周波数の弾性応答を考慮した 振動フィルタリング法を使用して, 高ひずみ速度で の振動の影響を排除した。この振動データを効果的 にフィルタリングする数值的方法として, SavitzkyGolayフィルタリング法を適用した。

（3）逆解析法を用いることによって, 流動応力曲線を取得 した。この計算結果と見かけの応力〜軸方向ひずみ曲 線との比較を行い, 両者が大きく異なる主な理由が, 内部発熱と不均一な変形につながる不均一な温度分布 であることを明らかにした。

（4）独立パラメータ, ひずみ速度依存指数, 温度依存指数 の回帰を行い，広範囲のひずみ速度，ひずみ，温度に 対応した流動応力統合式曲線を取得した。

（5）中ひずみ速度データから回帰した流動応力曲線を高ひ ずみ速度の領域まで外挿し，本研究で得られた回帰流 動応力曲線と比較した。外挿された流動応力曲線の定 常応力は, 直接得られた結果とは大きく異なるものと なった。この違いは, 高ひずみ速度の変形による双晶 効果が原因である可能性がある。以上から低ひずみ速 度および中ひずみ速度から高ひずみ速度への外挿法は 不適切であると結論付けることができる。 


\section{文献}

1) T.Senuma, H.Yada, Y.Matsumura and T.Futamura: Tetsu-toHagané, 70(1984), 2112 (in Japanese). https://doi.org/10.2355/ tetsutohagane1955.70.15_2112

2 ) J.Yanagimoto: Mater. Trans., 50(2009), 1620. https://doi.org/10. 2 320/matertrans.MF200906

3 ) M.Soltanpour and J.Yanagimoto: J. Mater. Process. Technol., 212(2012), 417. https://doi.org/10.1016/j.jmatprotec.2011.10.004

4 ) E.Dupin, A.Yanagida and J.Yanagimoto: Steel Res. Int., 85(2014), 1099. https://doi.org/10.1002/srin.201300173

5 ) Y.Meng,J.-Y.Lin, A.Yanagida and J.Yanagimoto: Steel Res. Int., 88(2017), 1700036. https://doi.org/10.1002/srin.201700036

6 ) S.Ding, S.A.Khan and J.Yanagimoto: Mater. Sci. Eng. A, 728(2018), 133. https://doi.org/10.1016/j.msea.2018.05.025

7 ) J.Yanagimoto, Y.Kobayashi and A.Yanagida: Steel Res. Int., 78(2007), 812. https://doi.org/10.1002/srin.200706290

8 ) A.Yanagida, M.Ikeda, H.Komine and J.Yanagimoto: ISIJ Int., 52(2012), 574. https://doi.org/10.2355/isijinternational.52.574

9 ) G.Haugou, F.Fabis, B.Langrand, E.Deletombe and E.Markiewicz: Structures Under Shock and Impact, Vol. 7, WIT Press, Southampton, UK, (2002), 113.

10) H.-W.Park, K.Kim, H.-W.Park and J.Yanagimoto: ISIJ Int., 60(2020), 573. https://doi.org/10.2355/isijinternational.ISIJINT-2019-426
11) A.Yanagida, J.Liu and J.Yanagimoto: Mater. Trans., 44(2003), 2303. https://doi.org/10.2320/matertrans.44.2303

12) A.Yanagida and J.Yanagimoto: ISIJ Int., 45(2005), 858. https://doi. org/10.2355/isijinternational.45.858

13) H.Suzuki, S.Hashizume, Y.Yabuki, Y.Ichihara, S.Nakajima and K.Kenmochi: Rep. Inst. Ind. Sci. Univ. Tokyo, 18 (1968), No. 3, 139.

14) N.I.Vazquez-Fernandez, G.C.Soares, J.L.Smith, J.D.Seidt, M.Isakov, A.Gilat, V.T.Kuokkala and M.Hokka: J. Dyn. Behav. Mater., 5(2019), 221. https://doi.org/10.1007/s40870-019-00204-z

15) J.D.Seidt, V.-T.Kuokkala, J.L.Smith and A.Gilat: Exp. Mech., 57(2017), 219. https://doi.org/10.1007/s11340-016-0237-z

16) E.I.Poliak and J.J.Jonas: ISIJ Int., 43(2003), 692. https://doi. org/10.2355/isijinternational.43.692

17) J.J.Jonas, X.Quelennec, L.Jiang and É.Martin: Acta Mater., 57(2009), 2748. https://doi.org/10.1016/j.actamat.2009.02.033

18) S.Mandal, P.V.Sivaprasad and V.S.Sarma: Mater. Manuf. Process., 25(2010), 54. https://doi.org/10.1080/10426910903162985

19) A.Yanagida and J.Yanagimoto: J. Mater. Process. Technol., 151(2004), 33. https://doi.org/10.1016/j.jmatprotec.2004.04.007

20) S.Mandal, A.K.Bhaduri and V.S.Sarma: Metall. Mater. Trans. A, 43(2012), 2056. https://doi.org/10.1007/s11661-011-1012-5

21) Y.Z.Tian, L.J.Zhao, S.Chen, A.Shibata, Z.F.Zhang and N.Tsuji: Sci. Rep., 5(2015), 16707. https://doi.org/10.1038/srep16707 